\title{
HAKIKAT SPIRITUALITAS PELAYAN KRISTUS DAN IMPLIKASINYA BAGI HAMBA TUHAN MASA KINI
}

\author{
David Eko Setiawan"1), Anton Ishariyono2) \\ Sekolah Tinggi Teologi Tawangmangu, Sekolah Tinggi Teologi El-Shadday Surakarta \\ 1) Tromol Pos 1 Kalisoro RT. 1 RW. 4 Tawangmangu, Karanganyar, Jawa Tengah \\ 2) Jalan Sutan Syahrir no. 88 Widuran Solo, Jawa Tengah \\ Email: 1)davidekosetiawan14217@gmail.com, 2)aintunggul@gmail.com
}

\begin{abstract}
ABSTRAK: Semakin banyaknya data tentang kemerosotan nilai, makna dan tujuan dari para pelayan Kristus telah mendorong banyak orang untuk mempertanyakan kembali tentang spiritualitas pelayan Kristus yang sesungguhnya. Spiritualitas pelayan Kristus adalah pengalaman hidup individu yang terhubung dengan Kristus yang dinyatakan melalui emosi, perilaku dan sikap hidupnya. Pengalaman hidup itu merupakan suatu penjiwaan keyakinan yang di dalamnya bukan hanya berkaitan dengan kontemplasi jiwa saja, namun bersamaan dengan praksis iman yang mewujud dalam tindakan nyata. Dalam penelitian ini digali hakikat spritualitas pelayan Kristus dan implikasinya bagi hamba Tuhan masa kini. Peneliti menggunakan studi literatur untuk menjawab problem reseach yang ada. Permasalah tersebut terkait dengan pertanyaan, bagaimanakah hakikat spiritualitas pelayan Kristus dan implikasinya bagi hamba Tuhan masa kini? Diharapkan penelitian ini dapat berdampak secara praktis bagi setiap hamba Tuhan masa kini.
\end{abstract}

Kata Kunci: spritualitas, pelayan kristus, hamba tuhan

\section{THE ESSENSE OF SPIRITUALITY OF CHRIST SERVANT AND ITS IMPLICATION FOR THE SERVANT OF GOD TODAY}

\begin{abstract}
The increasing number of data about the decline in value, meaning and purpose of Christ's servants has prompted many people to question again about the spirituality of the true servant of Christ. The servant's spirituality of Christ is the experience of an individual's life connected with Christ expressed through his emotions, behavior and attitude. Life experience is an appreciation of conviction which is not merely related to the contemplation of the soul, but also concurrent with the praxis of faith that manifests in concrete actions. This study will explore the essence of the spirituality of Christ's servants and its implications for the current God's servants. The researcher is using literature studies to answer the research problem. The problem is correlated with the question: how are the nature of the spirituality of Christ's servants and their implications for God's servants today? It is expected that this research can have a practical impact on every servant of God today.
\end{abstract}

Keywords: spirituality, servants of christ, servants of god

\section{PENDAHULUAN}

Setiap orang yang terpanggil untuk melayani Kristus disebut sebagai pelayan Kristus. Namun demikian, pada tulisan ini, pengertian tentang pelayan Kristus akan dibatasi pada mereka yang terlibat dalam pelayanan gerejawi saja. Tujuan pembatasan ini adalah untuk memfokuskan pembahasan agar tidak terjadi pembiasan arti. Pelayan Kristus yang dimaksud dalam tulisan ini dibatasi pada golongan rohaniwan saja, yaitu pendeta atau gembala sidang, 
penginjil, pengajar dan pengerja gereja. Sedangkan istilah spiritualitas dibatasi pada spiritualitas Kristen. Mengapa demikian? Karena pada dasarnya spiritualitas Kristen itu unik. Keunikan spiritualitas Kristen terletak pada penghayatan yang jelas dan konkrit terhadap keteladanan hidup dan pelayanan Tuhan Yesus Kristus. Berkaitan dengan hal tersebut Herlianto menjelaskan pusat dari spiritualitas Kristen sebagai berikut (1990, pp. 51-82):

Spriritualitas Kristen pada dasarnya tidak hanya menggali kedalaman nilai-nilai yang transenden atau 'sumber-sumber asali' seperti yang dilakukan oleh Gerakan Spiritualitas Zaman Baru (GZB) yang meyakini bahwa Yang Transenden dapat memanifestasi melalui roh dunia atau alam semesta, namun berpusat secara jelas pada Kristus, yaitu Allah yang berinkarnasi.

Spiritualitas pelayan Kristus menjadi topik yang menarik untuk dibahas mengingat semakin banyaknya data tentang kemerosotan nilai, makna dan tujuan dari mereka. Munculnya beberapa skandal kekuasaan, keuangan dan seks yang melibatkan beberapa dari mereka membuktikan bahwa kemerosotan itu nyata. Beberapa skandal tersebut disoroti oleh Dermot antara lain, pada tahun 1980 pengkhotbah TV di Amerika telah menipu serta menyalahgunakan uang dari para pendukungnya untuk memuaskan nafsu seks mereka. Selanjutnya pada tahun 1990 juga ditemukan skandal pedofilia di gereja Katolik Roma yang melibatkan para imam mereka (Dermot, 1995, p. 16). Bahkan akhir-akhir ini kemerosotan tersebut mulai berdampak pada gereja dengan dibuktikan semakin maraknya para pemimpin gereja menerima perceraian sebagai solusi konflik pernikahan, pengejaran kekayaan serta status untuk kepentingan diri sendiri (Ipaq, 2014, p. 113).

Berdasarkan data di atas, degradasi nilai, makna dan tujuan para pelayan Kristus adalah sebuah fakta. Sebagai akibatnya masyarakat mulai meragukan keunikan kemurnian dan spiritualitas para pelayan Kristus. Bagaimanakah hakikat spiritualitas pelayan Kristus itu? Dan bagaimanakah implementasinya bagi hamba Tuhan masa kini? penelitian ini bertujuan untuk menunjukkan bagaimanakah hakikat spiritualitas pelayan Kristus dan implikasinya bagi hamba Tuhan masa kini.

\section{METODE}

Metode yang digunakan di dalam penelitian ini adalah menggunakan studi literatur. Peneliti berusaha menjawab masalah penelitian yang muncul dengan mencari sumber-sumber literatur yang berkorelasi dengan masalah penelitian tersebut. Teknik pengumpulan data pada penelitian ini dilakukan dengan cara membaca, menelaah dan mencatat berbagai bahan literatur yang sesuai dengan pokok bahasan, kemudian disaring dan dituangkan dalam kerangka pemikiran secara teoritis (Kartono, 1980, p. 78). Adapun sumber-sumber literatur tersebut adalah buku-buku teks dan juga jurnaljurnal penelitian.

Beberapa buku sumber literatur yang digunakan dalam penelitian ini adalah bukubuku karya H. J. M. Nouwen, William Barclay, Earl Wilson dan V. I. Tanya. Peneliti juga mencermati beberapa teks Alkitab Perjanjian Baru yang relevan dengan topik penelitian. Selanjutnya data-data yang terkumpul tersebut diolah dengan beberapa langkah berikut, pertama, peneliti melakukan pemeriksaan data. Kedua, peneliti mengelompokkan data yang telah diedit dan diberi kode. Ketiga, peneliti melakukan rekonstruksi data dengan menyusunnya secara teratur. Keempat, peneliti menempatkan data menurut sistematika bahasan di dalam penelitian ini.

Kemudian peneliti menganalisis datadata tersebut dengan menggunakan analisis dokumen atau analisis isi. Analisis isi merupakan kajian yang menitik beratkan pada interpertasi bahan tertulis berdasar 
konteksnya untuk mendapatkan jawaban atas masalah penelitian.

\section{HASIL DAN PEMBAHASAN}

\section{Pengertian Spiritualitas}

Ditinjau secara etimologis, kata spritualitas berasal dari kata spirit yang diturunkan dari bahasa Latin spiritus yang berarti nafas (breath), keteguhan hati (courage), kekuatan (vigor), jiwa (soul), dan hidup (life) (Russell, Bean \& Vaughan, 1938, p. 1597). Tischler dan McKeage (2002, p. 203), mengatakan bahwa spiritualitas berhubungan dengan emosi atau perilaku dan sikap tertentu dari seorang individu. Sedangkan menurut Schippers (2004, p. 9), spiritualitas merupakan suatu penghayatan iman yang di dalamnya tidak hanya menyangkut suatu pengalaman, tetapi sekaligus sebuah praktik beriman.

Sehubungan dengan spiritualitas Kristen, Tanujadja (2002, p. 177) mendefinisikannya sebagai keberadaan seseorang yang tahu bagaimana ia seharusnya berelasi dengan sesama, diri sendiri, dan ciptaan lain, serta hidup berdasarkan pengetahuan tersebut.

Akhirnya spiritualitas dalam tulisan ini dapat didefinisikan sebagai pengalaman hidup individu yang terhubung dengan Kristus yang dinyatakan dalam pikiran, perasaan dan kehendak serta mewujud dalam sikap hidup sehari-hari. Sikap hidup tersebut merupakan suatu penghayatan iman yang melibatkan relasi dengan Allah, diri sendiri dan sesamanya.

\section{Spiritualitas dan Pelayanan}

Menurut Nouwen (1986, p. 21) spiritualitas dan pelayanan tidak pernah dapat dipisahkan, karena pelayanan bukanlah sekadar sebuah pekerjaan dengan jam kerja tertentu, akan tetapi pertama-tama pelayanan merupakan jalan hidup yang perlu dilihat dan dimengerti oleh orang lain.

Namun demikian didapati fakta bahwa keduanya sering dipisahkan oleh sebagian pelayan Kristus. Hal itu akan memberi dampak buruk bagi pelayan Kristus tersebut dan juga dunia pelayanan. Berkaitan dengan hal itu maka pada bagian ini dijelaskan tentang rohaniwan dan dunia pelayanan, hakikat spiritualitas pelayan Kristus, spiritualitas pelayan Kristus dalam berbagai bidang pelayananya serta berbagai godaan bagi spiritualitas pelayan Kristus.

\section{Para Rohaniwan dan Pelayanannya Berdasarkan Alkitab}

Para Rohaniwan tidak dapat dipisahkan dengan dunia pelayanan. Mereka bukan saja dituntut bertanggung jawab dalam menyelenggarakan sebuah pelayanan, tetapi juga wajib menjadi panutan bagi umat Allah. Namun ternyata terdapat fakta bahwa ada sebagian rohaniwan yang tetap melaksanakan tugas pelayanan meskipun telah gagal menjadi panutan. Hal ini membuktikan kegagalan spiritualitas mereka.

Ada beberapa contoh Alkitab tentang hal tersebut. Pertama, Imam Eli. Dia adalah imam besar Israel di kota Silo. Eli adalah orang Lewi dari garis keturunan Itamar bin Harun. Dia memiliki dua orang anak yaitu Hofni dan Pinehas. Kegagalan spiritualitas Imam Eli dinyatakan dalam 1 Samuel 2:2829 sebagai berikut:

Dan Aku telah memilinnya dari segala suku Israel menjadi imam bagi-Ku, supaya ia mempersembahkan korban di atas mezbah-Ku, membakar ukupan dan memakai baju efod di hadapan-Ku; kepada kaummu telah Kuserahkan segala korban api-apian orang Israel. Mengapa engkau memandang dengan loba kepada korban sembelihan-Ku dan korban sajian-Ku, yang telah Kuperintahkan, dan mengapa engkau menghormati anak-anakmu lebih dari pada-Ku, sambil kamu menggemukkan dirimu dengan bagian yang terbaik dari setiap korban sajian umat-Ku Israel.

Eli dipilih Allah sebagai imam besar, namun ternyata dia gagal karena meman- 
dang dengan loba kepada korban sembelihan dan korban sajian. Selain itu dia juga menghormati anak-anaknya, yang jahat, lebih dari pada Allah. Akibat kegagalan spiritualitasnya itu, dia berserta kaum keluarganya dihukum oleh Allah (1 Sam. 2:3036). Namun demikian, Eli tetap melaksanakan tugasnya meskipun spiritualitasnya gagal (1 Sam. 3-4).

Kedua, Imam Elyasib. Dia diangkat untuk mengawasi bilik-bilik rumah Allah (Neh. 13:4). Namun dia malahan menjalin kerja sama dengan Tobia yang pada dasarnya adalah musuh (Neh. 4:1-23). Imam Elyasib membuatkan bilik bagi Tobia di pelataran rumah Allah (Neh. 13:7). Kegagalan spiritualitas Imam Elyasib ini membuat Nehemia marah karena dengan sikapnya tersebut membuat rumah Allah tidak tahir (Neh. 13:7-9).

Ketiga, ahli Taurat dan orang Farisi pada zaman Yesus. Yesus dengan jelas berbicara kepada orang banyak dan para murid untuk menuruti dan melakukan segala sesuatu yang mereka ajarkan, tetapi jangan turuti perbuatan-perbuatannya (Mat. 23:1-3). Mengapa demikian? Karena ahli Taurat dan orang Farisi itu mengajarkan sesuatu tetapi mereka tidak melakukannya (Mat. 23:3). Kegagalan spiritualitas mereka mendapat celaan dari Yesus sehingga orang Farisi dan ahli Taurat disebut "celaka" (Mat. 23:13-29).

Beberapa contoh di atas mengindikasikan bahwa pemisahan antara spiritualitas dan pelayanan pada diri seorang pelayan telah terjadi sejak masa lalu. Dan sejak awal, Allah tidak menginginkan hal tersebut.

Rupanya Rasul Paulus menyadari pentingnya keutuhan antara spiritualitas dengan pelayanan. Hal ini nampak dalam nasihatnya kepada Timotius dalam 1 Timotius 4:16 berikut:

Awasilah dirimu sendiri dan awasilah ajaranmu. Bertekunlah dalam semuanya itu, karena dengan berbuat demikian engkau akan menyelamatkan dirimu dan semua orang yang mendengar engkau.
Rasul Paulus menasehati Timotius untuk tetap memperhatikan kesesuaian tingkah laku dan ajarannya agar dapat menyelamatkan dirinya sendiri dan orang lain dari penyesatan. Paulus tidak ingin anak didiknya tersebut memisahkan spiritualitas dari pelayanan yang sedang dikerjakannya. Timotius harus hidup berlawanan dengan para pengajar palsu saat itu, yang hidup dengan spiritualitas yang salah dan pengajaran yang sesat (1 Tim. 6: 2b-21). Tantangan dari pengajar sesat harus dilawan dengan kesesuaian antara spritualitas dan pengajaran.

\section{Hakikat Spiritualitas Pelayan Kristus}

Bagaimanakah hakikat spiritualitas pelayan Kristus masa kini? Berdasarkan pernyataan Anggu (2005, p. 30) bahwa segala ajaran tentang pribadi dan karakter Kristen terdapat di dalam Galatia 5:22, 23, 25 maka bagian tersebut dapat menjadi rujukan untuk mengerti bagaimanakah seharusnya spiritualitas pelayan Kristus masa kini. Pendapat ini rupanya selaras dengan definisi spiritualitas Kristen yang diungkapkan oleh Tanja (1996, p. 9) sebagai sebuah sikap hidup yang berbuahkan kasih, sukacita, damai sejahtera, kesabaran, kemurahan, kebaikan, kesukaan, kelemahlembutan, dan penguasaan diri. Dari sini tampak bahwa keduanya saling terkait satu dengan yang lain. Sehingga melalui Galatia 5:22-23, hakikat spiritualitas pelayan Kristus masa kini dapat diidentifikasi.

Adapun hakikat spiritualitas pelayan Kristus tersebut adalah sebagai berikut, pertama, sikap hidup yang mengamalkan kasih. Kasih yang diamalkan itu adalah óyórm (agape). Mengapa demikian? Karena agape adalah jenis kasih yang berbeda dengan jenis yang lainnya. Barclay (2000, p. 79) menjelakan adanya empat kata di dalam bahasa Yunani yang merujuk pada kasih, pertama, eros adalah cinta-birahi antara pria dan wanita. Kedua, filia adalah kasih yang memberikan kehangatan kepada orang yang paling dekat dan dikasihi. Ketiga, 
storge yang lebih tepatnya diterjemahkan sebagai kasih sayang dalam hubungannya antara orang tua dan anak-anak. Keempat, agape yang berarti kebajikan yang tak dapat dilawan. Pada dasarnya agape merupakan kata benda yang berasal dari kata kerja agapao (Bauer, 2010, pp. 4-5). Agape merupakan jenis kasih yang di dalamnya terdapat upaya yang disengaja untuk dilakukan tanpa ada maksud jahat, baik untuk diri sendiri maupun orang lain yang mungkin malah bermaksud jahat (Barclay, 2000, p. 80). Bahkan, jenis kasih ini dapat memberikan dorongan untuk menghadirkan pelayanan yang terbaik bagi orang (Petterson, 2010, pp. 67-76). Sehingga tidaklah berlebihan jika agape sering disebut kasih tanpa syarat. Mengingat pengamalannya memerlukan pengorbanan yang sejati tanpa menuntut balasan dari sang objek agape (Hendra, 2015, p. 50). Melalui agape seorang pelayan Kristus akan lebih memaknai pelayanan yang sesungguhnya. Pelayanan berarti pengorbanan bukan tempat untuk mencari keuntungan semata. Bahkan melalui agape, dia akan lebih meningkatkan mutu pelayanan kepada Allah dan sesama tanpa menuntut adanya balasan apapun. Agape menolong sang pelayan untuk menjaga kemurnian pelayanannya.

Kedua, Sikap hidup yang dipenuhi sukacita. Kata sukacita merupakan terjemahan dari kata Yunani $x \alpha \rho \dot{\alpha}$ (khara). Kata ini menunjukkan sebuah perasaan batin yang menyenangkan atau suatu keadaan yang penuh dengan sukacita (Bauer, 2010, p. 875). Khara tidaklah sama dengan kebahagiaan, karena kebahagiaan tergantung pada keadaan, sedangkan khara merupakan hasil dari relasi dengan Allah (Crowther, 2017, p. 27). Bahkan jenis sukacita ini tidak dapat dipengaruhi oleh situasi apapun. Mengingat khara tidak bersumber dari keduniawian namun merupakan penggenapan janji Kristus bagi setiap orang yang ada di dalam-Nya (Brown, 1971, p. 357). Malahan menurut Crowther (2017, p. 27) dengan mengutip pendapat Fung
(1988), sukacita ini dapat memberikan kekuatan di saat menghadapi berbagai masalah dan kesusahan. Melalui khara, kehidupan pelayan Kristus akan lebih stabil, karena memiliki kekuatan di dalam menghadapi berbagai macam godaan dalam pelayan serta orientasi pelayanan yang tidak terpukau dengan keduniawian melainkan hanya kepada Allah saja.

Ketiga, Sikap hidup yang dipenuhi damai sejahtera. Kata damai sejahtera di dalam bahasa Yunani adalah Eipńvn (eirene). Di dalam Alkitab Perjanjian Baru, eirene biasanya diartikan sama seperti shalom yang tidak hanya sekadar berarti kebebasan dari kesulitan, tetapi segala hal yang membawa kebaikan tertinggi bagi manusia (Barclay, 1974, p. 148). Damai sejahtera adalah watak yang muncul di dalam diri orang percaya akibat keseluruhan proses pengudusan, pemeliharaan dan penyempurnaan di dalam Kristus (Brown, 1971, p. 781). Selanjutnya, Crowther (2017, pp. 30-31) mengutip Collin, menjelaskan damai sejahtera sebagai keutuhan di dalam diri seseorang yang menyebabkan ketiadaan konflik dalam batinnya. Maka dari itu seorang pelayan Kristus yang hidupnya dipenuhi dengan damai sejahtera ditandai dengan ketenangan hati yang bersumber dari kesadaran bahwa kehidupannya berada di dalam tangan Tuhan (Barclay, 1974, p. 148). Ketenangan hati ini akan mempengaruhi pelayanannya kepada Allah dan sesama. Melalui eirene, sang pelayan menjadi pendamai di setiap konflik. Kekuatiran hidup tidak akan menurunkan kuantitas dan kualitas pelayanannya, mengingat apapun yang dikerjakannya dikuasai oleh ketenangan hati yang bersumber dari Allah.

Keempat, sikap hidup penuh kesabaran. Kesabaran merupakan terjemahan dari bahasa Yunani $\mu \alpha \kappa \rho o \theta u \mu i \alpha$ (makrothumia). Kata makrothumia diartikan sebagai sikap tekun dan sabar yang membawa kemenangan (Barclay, 1974, p. 196). Makrothumia mengandung makna kesabaran terhadap manusia yang ditandai dengan 
kemampuan untuk menahan amarah dan tidak membalas dendam. Kata ini dipakai di dalam Perjanjian Baru untuk menunjukkan kesabaran Allah terhadap manusia (Rm. 2:4; 9:22; 1 Tim. 1:16; 1 Ptr. 3:20). Di dalam Perjanjian Baru, kata ini juga digunakan untuk menunjukkan karakteristik orang percaya yang telah disatukan dengan Allah melalui Kristus (Brown, 1971, p. 769). Berdasarkan hal tersebut maka orang percaya wajib meneladani kesabaran Allah terhadap manusia. Hal inilah yang menjadikan alasan bagi orang percaya untuk sabar terhadap sesama serta tidak marah serta membalas dendam atas perlakuan mereka. Pelayan Kristus seharusnya memiliki sikap hidup yang dipenuhi dengan kesabaran. Kesabaran itu akan menolong dia untuk menahan amarah serta tidak membalas dendam ketika diperlakukan tidak adil oleh sesama. Melalui kesabaran, dia dapat menyelesaikan setiap masalah dalam kehidupan sehari-hari tanpa harus terprovokasi.

Kelima, sikap hidup penuh dengan kemurahan. Kata kemurahan dalam bahasa Yunani adalah хрпото́тпs (khrestotes) yang berarti kemurahan namun juga sering diartikan sebagai kebaikan (Barclay, 2000, pp. 81-82). Kata ini digunakan untuk menunjukkan kemurahan Allah dalam menyediakan keselamatan bagi umat manusia (Crowther, 2017, p. 29). Selanjut-nya, Crowther (2017, p. 29) dengan mengutip pandangan Schreiner (2010), menerangkan bahwa kemurahan hati Allah tersebut menjadi dasar bagi setiap orang percaya ketika berbuat baik kepada sesama tanpa harus mempertimbangkan balasannya. Kemurahan adalah sikap ramah terhadap orang lain bahkan kepada mereka yang enggan untuk menerimanya atau bahkan cenderung untuk melawan (Crowther, 2017, p. 29). Spiritualitas ini perlu ada pada setiap pelayan Kristus agar mereka tetap menunjukkan sikap ramah terhadap siapa pun bahkan kepada mereka yang jelas-jelas menentangnya. Kemurahan hati akan memurnikan motif para pelayan Kristus dalam melayani Allah dan sesama.

Keenam, sikap hidup yang penuh dengan kebaikan. Kata óyơ $\theta \sigma u ́ v \eta$ (agathosune) merujuk kepada sebuah kualitas moral yang unggul, jujur serta ketulusan jiwa yang membenci kejahatan (Barclay, 2000, p. 81). Pada bagian ini dengan mengutip pandangan Schreiner (2010), Crowther (2017, p. 30) menjelaskan bahwa mereka yang memiliki Roh Kudus dikuatkan untuk dapat menjalani kehidupan yang indah secara moral serta dapat bersinar terang di tengah dunia yang jahat, melaluinya setiap pelayan Kristus wajib menunjukkan sikap hidup yang penuh dengan kebaikan. Dengan agathosune tersebut, mereka didorong untuk memiliki karakter yang baik serta menjalani moralitas hidup yang unggul di tengah-tengah dunia. Spiritualitas tersebut menjadi sangat berarti di tengah-tengah moralitas manusia masa kini yang cenderung mengalami degradasi akibat nilainilai yang salah. Pelayan Kristus dapat menjadi teladan yang nyata akan hal tersebut.

Ketujuh, sikap hidup yang setia. Kata setia didalam bahasa Yunani adalah піотІৎ (pistis) yang memiliki arti layak untuk dipercaya (Barclay, 2000, p. 82). Crowther (2017, p. 30) dengan mengutip penjelasan Schreiner (2010), menerangkan bahwa pistis juga memiliki pengertian sifat seseorang yang dapat diandalkan dalam menyelesaikan tanggung jawabnya. Kesetiaan menuntut penghargaan atas komitmen yang telah dibuat oleh seseorang kepada Allah dan sesama meskipun hal itu tidak menyenangkan (Gibbons, 2009, pp. 1-8). Walapun kesetiaan merupakan komitmen internal namun itu dapat terlihat dalam perilaku seseorang (Crowther, 2017, p. 30). Spiritualitas ini seharusnya ada pada pelayan Kristus masa kini. Mereka dapat diandalkan dalam tanggung jawabnya terhadap Allah dan sesama. Meskipun berat namun dia tetap mampu diandalkan untuk menuntaskan setiap tanggung jawabnya tersebut.

Kedelapan, sikap hidup yang lemah 
lembut. Kelemahlembutan merupakan terjemahan dari kata dalam bahasa Yunani прхütпs (prautes). Kata ini diartikan sebagai pengendalian diri yang hanya dapat diberikan oleh Kristus saja (Barclay, 2000, p. 82). Kelemahlembutan adalah kualitas kerendahan hati yang rela mempedulikan orang lain (Bauer, 2010, p. 699). Crowther, (2017, p. 31) mengutip Collins, menjelaskan bahwa kelemahlembutan merupakan watak yang tenang terutama ketika mendapatkan kritikan tajam dan dapat berespon dengan cara yang tepat serta sanggup memaafkan dan mengoreksi kesalahan. Spiritualitas ini perlu ada pada setiap pelayan Kristus agar pelayanannya dapat menyentuh setiap orang bahkan mungkin orang yang keras dan suka mengkritik tajam. Sikap hidup yang lemah lembut akan menolongnya dalam menghadapi berbagai karakter manusia yang dilayani.

Kesembilan, sikap penguasaan diri.

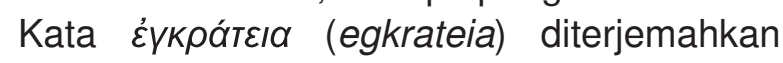
sebagai penguasaan diri. Dalam bahasa Yunani sehari-hari kata tersebut merujuk pada kearifan seorang kaisar yang tidak pernah membiarkan kepentingan dirinya sendiri mempengaruhi jalannya pemerintahan atas rakyatnya (Barclay, 2000, p. 83). Pelayan Kristus harus mewarnai kehidupan pribadi dan pelayanannya dengan spiritualitas tersebut. Kepentingan pribadinya janganlah menjadi motor penggerak pelayananya. Jika ini terjadi maka akan merusak pelayanannya kepada Allah dan sesama.

\section{Spiritualitas Pelayan Kristus dalam Beberapa Bidang Pelayanan}

Sehubungan dengan hakikat spiritualitas pelayan Kristus masa kini, Nouwen (1986, pp. 27-120) menujukkan pentingnya keterlibatan hal tersebut di dalam beberapa bidang pelayanan berikut: pertama, mengajar. Bidang pengajaran adalah bidang yang penting untuk diwarnai oleh spiritualitas pelayan Kristus. Mengapa demikian? Menurut Nouwen (1986, p. 59) Karena di saat mengajar, seorang pelayan Kritus sedang melaksanakan tugas pembebasan. Umat Allah dibebaskan dari kebodohan akan Firman Allah. Saat dia mengajar, jangan hanya mementingkan isi ajaran saja namun juga harus memperhatikan relasi antara pengajar dan yang diajar. Di sinilah spiritualitas pelayan Kristus hadir. Melalui spiritualitas ini relasi guru dan murid dibangun. Inti dari sebuah pelayanan di bidang pengajaran adalah bagaimana seorang pelayan membuat suatu hubungan dalam suatu proses pengajaran yang tidak diwarnai dengan persaingan, proses satu arah, dan sikap hidup yang mengasingkan, melainkan proses pengajaran yang membebaskan. Proses pengajaran yang membebaskan ini diwarnai dengan kesabaran, kelemahlembutan, keramahan, keterbukaan dan sikap saling menerima antara kedua belah pihak. Dalam proses ini pun ada kesejajaran status, sehingga arah pembelajaran yang terjadi adalah dua arah.

Berdasarkan teladan Kristus, Sang Guru Agung, pelayan Kristus dapat menggunakan salah satu metode pembelajaran Kristus, yaitu menggunakan pertanyaanpertanyaan. Metode ini mendorong situasi pembelajaran yang menekankan relasi guru dan murid. Melalui metode ini pula Kristus dapat menggambarkan jawaban yang benar bagi pendengar-Nya. Melalui penggambaran jawaban yang benar itu, jawaban akan lebih menyakinkan dan selalu mereka ingat dari pada hanya diucapkan saja.

Spiritualitas pelayan Kristus dalam bidang pengajaran tampak dari bagaimana dia mengembangkan relasi dengan umat Allah. Seorang pelayan Kristus seharusnya tidak sekadar mengajar namun juga membangun relasi yang penuh dengan kesabaran, kelemah-lembutan, keramahan serta keterbukaan pada orang-orang yang diajarnya. Kehadiran relasi dalam proses pembelajaran akan berdampak pada efektifitas penyerapan kebenaran pada umat Allah.

Kedua, berkhotbah. Nouwen (1986, p. 59) menjelaskan bahwa berkhotbah meru- 
pakan salah satu inti pelayanan Kristen. Namun demikian, berkhotbah bukanlah sekadar menceritakan kisah-kisah dalam Alkitab saja, tetapi di dalamnya harus ada kehidupan yang dibagikan. Hal ini membutuhkan keterbukaan dari sang pengkhotbah. Melalui hidupnya, diharapkan jemaat dapat mengenali dan memahami karya Allah. Sang pengkhotbah harus mampu memberikan keteladanan. Sebuah teladan hidup yang baik adalah khotbah terbaik yang dapat disampaikan kepada semua orang. Berkhotbah pada dasarnya bukanlah sekadar tugas di atas mimbar namun mencakup juga perilaku hidup sehari-hari. Di sinilah spiritualitas pelayan Kristus diuji. Pelayan Kristus harus hidup dalam keterbukaan agar spiritualitasnya dapat dilihat oleh semua orang sehingga mendorong lahirnya keteladanan. Dia bukan saja mahir dalam berkhotbah namun harus juga mampu memberikan teladan bagi sesama.

Ketiga, pelayanan pastoral. Nouwen (1986, p. 72) berpendapat bahwa seperti halnya mengajar dan berkhotbah, maka pelayanan pastoral pun juga terkait erat dengan spiritualitas seorang pelayan Kristus. Pada pelayanan tersebut, pelayan Kristus harus memilki kepedulian terhadap umat Allah. Untuk dapat peduli maka dibutuhkan keputusan menyangkal diri sendiri. Tujuannya dapat menciptakan ruang bagi Allah berkarya dalam diri seseorang.

Selain itu Nouwen (1986, p. 73) dengan tegas mengatakan bahwa hubungan pastoral tidak dapat sepenuhnya dimengerti dalam rangka kontrak professional. Hubungan pastoral lebih didasarkan pada kepedulian, di mana si pelayan ikut terlibat tanpa syarat ke dalam kehidupan/pergumulan sesamanya.

Pernyataan di atas selaras dengan nasihat Rasul Paulus kepada Timotius ketika dia sedang melayani di Efesus. Adapun nasihatnya adalah sebagai berikut: "Jangan seorang pun menganggap engkau rendah karena engkau muda. Jadilah teladan bagi orang-orang percaya, dalam per- kataanmu, dalam tingkah lakumu, dalam kasihmu, dalam kesetiaanmu dan dalam kesucianmu (1 Tim. 4:12). Barclay (2000, pp. 154-155) mengomentari bagian kasih pada ayat tersebut sebagai berikut:

Biasanya kasih merupakan sesuatu yang
berkaitan dengan hati tetapi jelas bahwa
kasih Kristen berkaitan dengan kehendak.
Kasih adalah penaklukkan diri, yang
dengannya kita menumbuhkan kepedulian
terhadap orang lain. Dengan demikian, ciri
pertama seorang pemimpin Kristen adalah
kepedulian terhadap orang lain, tidak
peduli apapun yang mereka lakukan
terhadap dirinya.

Berdasarkan penjelasan di atas tampak bahwa Paulus ingin Timotius memiliki kepedulian yang lahir dari óyórmn (agape) dalam menangani masalah-masalah pastoral di gereja Efesus. Inilah spiritualitas pelayan Kristus dalam pelayanan.

Keempat, berorganisasi. Nouwen (1986, pp. 86-119) melihat bahwa pelayan kristiani seringkali cenderung fokus pada struktur berorganisasi yang ada dalam gereja, bukan struktur kehidupan jemaat itu sendiri. Maksudnya, pelayan kristiani kadang tidak dapat menyentuh strukturstruktur kehidupan yang paling mendasar seperti kasih, pelayanan dan lain-lain. Hal ini disebabkan para pelayan tersebut terlalu sibuk berorganisasi dan mengabaikan umat Allah yang seharusnya perlu dilayani. Nouwen memberi contoh gereja membantu orang-orang miskin dengan memberikan mereka sejumlah uang atau tempat tinggal sementara. Padahal, mereka membutuhkan hal yang lebih dari itu yaitu sebuah kasih dan penghargaan sebagai seorang manusia, sehingga mereka bisa merasakan diterima dalam masyarakat. Kesalahan orientasi ini disebabkan para pelayan lebih cenderung melayani organisasi dari pada manusianya. Seharusnya, Umat Allahlah yang menjadi fokus pelayanannya.

Seorang pelayan Kristus harus benarbenar mempengaruhi bidang pelayanan ini 
dengan spiritualitasnya. Pelayanan yang penuh dengan kesabaran, kemurahan dan kesetiaan merupakan spiritualitas mereka dalam berorganiasi.

\section{Berbagai Godaan bagi Spiritualitas Pelayan Kristus}

Seorang pelayan Kristus tidak luput dari godaan di dalam pelayanannya. Jika seorang pelayan Kristus tidak menyikapi secara benar berbagai godaan itu, maka akan berdampak langsung pada spiritualitasnya. Berbagai godaan yang perlu diperhatikan oleh setiap pelayan Kristus adalah sebagai berikut:

Pertama, godaan di bidang keuangan. Adakalanya seorang pelayan Kristus diperhadapkan dengan masalah keuangan. Kasus-kasus penyalahgunaan keuangan oleh sebagian para pelayan Kristus telah menjadi catatan hitam bagi dunia pelayanan Kristen. Mereka yang memiliki posisi penting dalam mengambil keputusan tentang keuangan adakalanya diperhadapkan dengan godaan ketamakan dan integritas yang rendah. Tidak sedikit dari mereka yang gagal dalam bidang keuangan akibat gagal mengatasi godaan tersebut. Rasul Paulus dalam suratnya kepada Timotius (1 Tim. 6:10) mengingatkan bahaya cinta uang yang dapat merusak spiritualitas seseorang, demikianlah peringatannya: "Karena akar segala kejahatan ialah cinta uang. Sebab oleh memburu uanglah beberapa orang telah menyimpang dari iman dan menyiksa dirinya dengan berbagai-bagai duka." Setiap pelayan Kristus seharusnya memperhatikan nasihat Paulus tersebut. Karena hancurnya spiritualitas pelayan Kristus dimulai ketika orientasi pelayanannya telah bergeser kepada harta/uang. Berrs (1990, p. 961) menjelaskan jikalau seorang pelayan Kristus melayani hanya karena upah (baca: uang), maka pelayanannya memiliki motif yang rendah. Hal ini patut diwaspadai agar mereka tetap setia pada panggilannya.

Kedua, tantangan dalam hal seks. Sejak zaman Alkitab hingga masa kini, penyelewengan seksual telah menjadi catatan hitam. Kejatuhan sebagian pelayan Kristus karena seks telah mengakibatkan rusaknya reputasi dunia pelayanan Kristen dan mundurnya beberapa dari mereka. Kegagalan Daud di bidang seks (2 Sam. 11) seharusnya menjadi pelajaran penting bagi para pelayan Kristus untuk serius mengatasi godaan tersebut. Yusuf telah menunjukkan kekuatan integritasnya terhadap godaan seksual. Dia menolak dengan tegas godaan tersebut (Kej. 39). Meskipun harus menghadapi fitnahan dari istri Potifar.

Seorang pemimpin Kristen harus berani menghadapi godaan seksual dalam kepemimpinannya. Mengingat seksualitas tidak dapat diceraikan dengan spiritualitas (Foster, 1985, p. 91). Wilson (1990, pp. 807810) menunjukkan bagaimana pertumbuhan kristiani dapat dirintangi oleh dosa seksual. Menurut Wilson (1990, p. 807) dosa seksual dapat menghalangi penyembahan kepada Allah. Ketika seseorang terlibat dengan dosa seksual maka dia akan mencurahkan segala perhatiannya kepada seks, sehingga dia akhirnya tidak mempunyai tenaga atau kecenderungan untuk menyembah Allah. Seseorang tidak dapat menyembah keduanya (Allah dan seks). Pastilah dalam hal ini akan ada yang dikorbankan. Padahal perintah tertinggi yang Allah berikan kepada orang percaya adalah untuk menyembah Allah. Di sinilah dosa seksual menjadi penghalang bagi spiritualitasnya.

Selanjutnya dosa seksual juga menghalangi pertumbuhan rohani dengan cara mengikat pada kesalahan seseorang. Dosa seksual telah mengakibatkan seseorang terikat pada sesuatu yang salah. Wilson (1990, p. 808) menjelaskan bahwa dosa seksual akan memberikan efek mengikat namun keterikatan pada sesuatu yang salah. Sehingga seseorang yang terikat olehnya, di satu sisi merasakan kenikmatan namun di sisi lain dia merasakan tekanan akibat perbuatannya yang salah. Ini membuat terhambatnya pertumbuhan rohani seseorang. Bahkan akan merusak spiritualitas- 
nya. Dosa seksual mengakibatkan seseorang berorientasi kepada hal-hal jasmaniah. Wilson (1990, p. 808) memaparkan hal tersebut melalui kesaksian kliennya yang mengatakan bahwa selama dia terikat pada dosa seksual maka dia sulit berpikir bahwa dirinya terdiri dari tubuh, jiwa dan roh. Karena dia selalu hanya memikirkan kenikmatan tubuhnya dan kemudian mengabaikan hal-hal rohani.

Wilson (1990, p. 809) juga berpendapat bahwa dosa seksual membuat seseorang percaya setiap perasaan senang dan bahagia harus bersifat seksual atau erotik. Kenikmatan fisik bersifat sementara, sedangkan kenikmatan dari Allah itu kekal (lbr. 11:24-28). Dosa seksual telah menipu seseorang sehingga dia hanya mengejar kenikmatan fisik saja dan mengabaikan kenikmatan dari Allah. Ini dapat menghambat spritualitas seseorang.

Akhirnya Wilson (1990, p. 810) mengatakan bahwa dosa seksual juga dapat membuat seseorang kehilangan kerinduan untuk dekat dengan Allah. Menurutnya, berdasarkan pernyataan Yesus dalam Matius 6:24, seseorang tidak dapat melayani Tuhan dan uang sekaligus. Demikian pula seseorang tidak dapat melayani dosa seks dan Allah sekaligus, karena keduanya bertentangan.

Ketiga, godaan dalam hal kekuasaan. Setiap pelayan Kristus diberi otoritas oleh Allah untuk menjadi servant leader bagi umat Allah. Namun demikian ada sebagian pelayan Kristus yang telah menyalahgunakan kekuasaan untuk kepentingan diri sendiri. Otoritas yang diterima seharusnya digunakan untuk melayani, namun tidak sedikit dari mereka yang gagal dalam menghadapi godaan penyalahgunaan kekuasaan tersebut. Mereka jatuh akibat kesombongan dan egoisme sehingga merasa diri benar dan akhirnya lupa bahwa sejatinya mereka adalah pelayan Kristus (Foster, 1985, p. 178).

Untuk dapat menghadapi godaan itu, seorang pelayan Kristus harus mengambil keputusan untuk memiliki fokus yang benar dalam melayani, yaitu menyenangkan Tuhan dan bukan dirinya sendiri. Jika fokus pelayanannya benar maka di saat yang bersamaan dia akan menerima promosi yang sesungguhnya dari Kristus. Tetapi jika dia melayani Kristus oleh karena hanya ingin mendapatkan posisi atau kekuasaan maka hal itu akan membuatnya jatuh. Dalam melayani Dia, pelayan Kristus itu sendiri akan bertumbuh secara rohani. Dia akan menjadi hamba yang lebih efektif, yang dipersiapkan untuk pelayanan lebih besar. Para pelayan Kristus harus mengingat bahwa otoritas atau kekuasaan diberikan kepada mereka bukan untuk popularitas diri sendiri namun untuk sebagai kesempatan untuk melayani Yesus lebih efektif lagi. Selanjutnya, kekuasaan itu juga digunakan untuk melayani orang-orang yang dipimpinnya dengan kasih, sehingga mereka pun akhirnya dapat merasakan kasih tersebut (Octavianus, 1994, p. 189).

\section{Implikasi Spiritualitas Pelayan Kristus bagi Hamba Tuhan Masa Kini}

Berdasarkan pembahasan sebelumnya, tampak bahwa spiritualitas pelayan Kritus mewujud dalam karakter Kristen yang terdapat di dalam Galatia 5:22, 23, 25. Itu menjadi sebuah sikap hidup yang dapat diidentifikasi sebagai hakikat spiritualitas pelayan Kristus masa kini.

Di tengah-tengah berbagai situasi dan tantangan pelayanan yang muncul saat ini diperlukan sosok hamba Tuhan yang mumpuni dalam menghayati spiritualitasnya. Tidak dapat dipungkiri bahwa masih sering ditemui spiritualitas pelayan Kristus yang merosot saat ini sehingga menimbulkan kesenjangan yang makin lebar antara fakta dengan harapan. Apa yang diharapkan adalah sebuah keteladanan seorang hamba Tuhan. Tentu kondisi ini harus menjadi perhatian. Jika tidak, secara umum akan berdampak buruk pada gereja Tuhan masa kini.

Apakah implikasinya? Pertama, akan semakin sulit didapati hamba Tuhan yang 
dapat dipercaya. Berbicara tentang dipercaya dalam lingkup hamba Tuhan ini sangat luas. Setidaknya jika ada hamba Tuhan yang tidak dapat dipercaya maka secara langsung ia mengajarkan ketidakjujuran kepada umat Tuhan yang dilayani. Tidak mengherankan jika akhir-akhir ini, sering terdengar hamba Tuhan yang jatuh dalam dosa seks, penyimpangan kuangan dan memperebutkan kekuasaan seolah berada di panggung politik. Menurut Danile (Spektrum, 2020) dalam surveinya didapati spiritualitas generasi muda Kristen di Indonesia menunjukkan bahwa $80 \%$ pemimpin Kristen gagal menjadi teladan yang baik. Fakta itu menjadi pertanda gagalnya hamba Tuhan dalam mengemban tugas sebagai pelayan Kristus. Menyangkut kehidupan gereja, hal kredibilitas sangat penting dalam kepemimpinan dan pertumbuhan gereja (Rajaguguk, 2018, p. 13).

Kedua, penggembalaan yang tidak benar akan menghasilkan jemaat yang tidak benar pula (Dharma, 2017, p. 8). Tidak heran jika akhir-akhir ini didapat jemaat Tuhan hidup dalam kecemaran, tidak memiliki integritas, tidak kudus, dan bergaya sekuler. Karena mereka melihat praktik hidup pemimpin-pemimpin yang tidak selaras dengan apa yang mereka bicarakan melalui mimbar khotbah atau di ruang kelas. Keteladanan yang buruk ini akan berdampak pada kehidupan rohani yang tidak berkarakter Kristus.

Ketiga, gereja akan kehilangan pengaruh atau tidak memberikan dampak positif bagi masyarakat luas. Gereja yang dimaksud di sini adalah persekutuan orang-orang yang telah dipanggil Allah di dalam dan melalui Yesus. Pemanggilan itu untuk satu tujuan agar menjadi milik-Nya, umat kepunyaan Allah sendiri. Sebab dengan pemanggilan itu, Allah mau supaya umat-Nya menjadi kudus, diperlengkapi dengan Roh Kudus agar menjadi serupa dengan Kristus. Dengan kata lain, orang-orang yang telah dipanggil itu akan mengalami proses terus menerus yang berkaitan dengan karak- ternya. Erastus Sabdono melihat banyak orang Kristen yang mengabaikan proses ini, mereka lebih mementingkan kesenangan diri sendiri, gelar, kekuasaan, kehormatan, harta kekayaan dan lain sebagainya (Sabdono, 2016, p. 51).

Gereja, baik lokal maupun global harus memberi dampak bagi masyarakat. Sebab Allah ingin menyelesaikan tujuan penebusan-Nya, yaitu agenda besar Allah, melalui gereja-Nya. Gereja jauh lebih penting dalam mengubah sebuah masyarakat dibandingkan kepala negara, atau lembaga perwakilan rakyat. Oleh sebab itu Allah mempersiapkan dan memberikan pemimpin kepada jemaat. Para pemimpin inilah yang harus memperlengkapi gereja untuk tujuan besar Allah. Ini adalah tugas tertinggi dari semua pemimpin gereja, yakni memperlengkapi umat Tuhan untuk melaksanakan pekerjaan Allah dan memperluas kekuasaan-Nya melalui pelayanan (Moffit \& Tesch, 2010, pp. 150-151).

Maka dari itu dibutuhkan seorang pemimpin umat yang dapat menjadi panutan bagi orang lain, sebab pemimpin dengan spiritualitas yang baik akan menjadi panutan dan berkat bagi jemaatnya (Rusmiyati, 2018, p. 11). Berbicara tentang pemimpin yang bisa menjadi panutan bagi orang lain, Yesus adalah model pemimpin yang ideal yang bisa menjawab kebutuhan masa kini. Model kepemimpinan Yesus secara garis besar sangat bertolak belakang dengan yang ada di dunia ini. Kepemimpinan sejalan dengan status, dominasi, dan kontrol. Yesus secara tegas menolak gaya autokrasi ini dan menuntut para pemimpin mempunyai ciri pelayanan yang rendah hati. Dalam hubungannya dengan para murid, Yesus secara konsisten memberi teladan melalui gaya kepemimpinan-Nya. Ketika Yesus membasuh kaki para murid, la mau supaya mereka mengikuti teladan-Nya (Yoh. 13:14). Inilah gaya kepemimpinan Yesus yang melayani (D'Souza, 2006, p. 170).

Selain gaya kepemimpinan Yesus yang melayani, Alkitab juga memperlihatkan 
gaya kepemimpinan gembala, yang peduli, dan memberikan bimbingan. Dalam Matius 14:13-21, ketika Yesus melihat orang banyak mengikuti-Nya sampai malam, la tidak hanya mengajar dan menyembuhkan orang sakit, tetapi juga memberi mereka makan sebelum pulang. Yesus memberi teladan kepedulian kepada murid-murid dengan menyuruh mereka memberi makan yang jumlahnya ribuan orang. Ini jelas perkara yang tidak mungkin dapat dilakukan oleh para murid. Dalam kebuntuan itu Yesus meminta apa yang ada pada mereka supaya la berkati dan bisa memenuhi kebutuhan ribuan orang. Yesus memberi perintah, juga sekaligus memberi bimbingan. Inilah kepemimpinan gembala.

Kepemimpinan menuntut kepercayaan. Ini adalah prasyarat untuk terlaksananya segala sesuatu yang hendak dicapai. Dan kepercayaan terbesar adalah warisan kepada mereka yang datang kemudian (James \& Barry, 2007, p. 41). Yesus adalah pemimpin yang ideal dan bisa dipercaya. la mau menyelesaikan tujuan penebusan-Nya melalui gereja-Nya. la telah meletakkan dasar yang kokoh melalui kepemimpinanNya kepada para murid. Dan para murid, sebut saja Petrus telah meneladani Yesus dengan menjadikan pengikutnya pemimpin umat. Dari Yesus diterima oleh Petrus, dari Petrus diteruskan kepada jemaat mulamula, yang kemudian dari sana proses penebusan terus berlangsung hingga sekarang melalui gereja-Nya.

Seperti apa kepemimpinan Petrus? Semula Petrus dikenal sebagai salah seorang rasul Yesus yang pernah menyangkal Dia. la juga dikenal sebagai orang yang tidak terpelajar di hadapan sidang Mahkah Agama (Kis. 4:13). Namun ia adalah murid yang setia dan menaati perintah Yesus. Ia juga mempelajari Kitab Suci. Dalam persekutuan doa ia memimpin dan menggerakkan murid-murid yang lain untuk menggenapi Mazmur 69:26; 109:8, yaitu menggantikan posisi Yudas yang sudah mati dengan Matias.
Dalam kepemimpinannya, Petrus mengajarkan bagaimana hidup berjemaat, yaitu bertekun belajar firman, berdoa, membangun hubungan kebersamaan di dalam Kristus, berbagi rezeki, murah hati, tidak mementingkan diri sendiri, hidup rukun dengan gembira (Kis. 2:41-47). Sekalipun pelayanan Petrus dan murid yang lain ditentang oleh Mahkamah Agama, namun ia lebih taat kepada Allah (Kis. 4:18-20). Ini adalah bukti pemimpin yang berprinsip.

Petrus adalah sosok hamba Tuhan yang memiliki pengalaman hidup sebagai pribadi yang terhubung dengan Kristus yang mewujud dalam emosi, perilaku, ketaatan dan kesetiannya. Dalam suratnya kepada jemaat yang hidup dalam perantauan, memperlihatkan kerinduannya kepada jemaat yang digembalakan maupun jemaat masa kini, dalam situasi apapun untuk tetap memiliki spiritualitas pelayan Kristus.

Tetapi kamulah bangsa yang terpilih, imamat yang rajani, bangsa yang kudus, umat kepunyaan Allah sendiri, supaya kamu memberitakan perbuatan-perbuatan yang besar dari Dia, yang telah memanggil kamu keluar dari kegelapan kepada terang-Nya yang ajaib: kamu, yang dahulu bukan umat Allah, tetapi yang sekarang telah menjadi umat-Nya, yang dahulu tidak dikasihani tetapi yang sekarang telah beroleh belas kasihan (I Petrus 2:9-10).

\section{KESIMPULAN}

Seiring dengan adanya sebagian penilaian negatif terhadap para pelayan Kristus masa kini maka mereka wajib untuk menghidupi spiritualitasnya. Adapun hakikat spiritualitas tersebut tersurat di dalam Galatia 5:22-25. Jika spritualitas ini tidak dihidupi oleh hamba Tuhan masa kini, maka akan berimplikasi pada semakin sulit ditemukan hamba Tuhan yang dapat dipercaya. Selain itu juga akan berimplikasi pada jemaat. Model penggembalaan yang tidak benar akan menghasilkan jemaat yang tidak benar pula. Akhirnya gereja akan 
kehilangan pengaruh positif bagi masyarakat luas.

\section{DAFTAR RUJUKAN}

Anggu, P. (2005). Pertumbuhan Karakter Kristen "Kepribadian Seorang Pelayan". Jurnal Jaffray, 3(1), 26-30.

Bauer, W. (2010). A Greek-English Lexicon of the New Testament and Other Early Christian Literature. Chicago: University of Chicago Press.

Barclay, W. (2000). Pemahaman Alkitab Setiap Hari: Surat-surat Galatia \& Efesus. Jakarta: BPK Gunug Mulia

(1974). New Testament Word. Kentucy: Westminster Press.

Brown, C. (1971). New Testament Theology (Vol. 2). Grand Rapids: Regency Reference Library from Zondervan.

Collins. (2006). The Power of Leadership. Hampton, VA: CFI Publishing.

Crowther, S. S. (2017). The Fruit of The Spirit in The Context of Leadership. Journal of Biblical Perspectives in Leadership, 7(1), 2434.

D'Souza, A. (2009). Ennoble, Enable, Empower. Jakarta: Kompas Gramedia

Dermot, G. R. Mc. (1995). Mengenali 12 Tanda Kerohanian Sejati (Suryadi, Trans.). Yogyakarta: Yayasan Andi.

Dharma, S. M. (2017). Kesesasatan Gereja Akhir Zaman. Yogyakarta: Andi

Foster, R. J. (1985). Uang, Sex dan Kekuasaan. Bandung: Yayasan Kalam Hidup

Fung, R. (1988). The Epistle to the Galatians. Grand Rapids: Eerdmans

Gibbons, S. (2009). Patience: The Fourth in a Series of Nine Leadership Devotionalsbased upon the Fruit of the Spirit. Inner Resources for Leaders, 2(1), 1-8.

Hendra, V. (2018). Peran Orang Tua dalam Menerapkan Kasih dan Disiplin kepada Anak Usia 2-6 Tahun sebagai
Upaya Pembentukkan

Karakter. Kurios: Jurnal Teologi dan Pendidikan Agama Kristen, 3(1), 4865.

Herlianto. (1990). Humanisme dan Gerakan Zaman Baru. Yayasan Kalam Hidup.

Ipaq, E. W. (2014). Pemimpin Sebagai Gembala. Jurnal Jaffray, 12(1), 2734.

Kartono, K. (1980). Pengantar Metodologi Research. Bandung: Alumni.

Moffit, B. \& Tesch, K. (2010). Transformasi Gereja Lokal dan Masyarakat. Jakarta: Bina Kasih,

Nouwen, H. J. M. (1986). Pelayanan yang Kreatif. Yogyakarta: Kanisius.

Octavianus, P. (1994). Manejamen dan Kepemimpinan Menurut Wahyu Allah. Malang: YPPI dan Gandum Mas.

Sabdono, E. (2016). Resurrecting Jesus Within Us. Jakarta: Rehobot Literature

Schippers, K. (2004). Spiritualitas dan Pembangunan Jemaat. Seri Pastoral 367 No. 12. Yogyakarta: Kanisius.

Schreiner, T. (2010). Exegetical commentary on the New Testament: Galatians. Grand Rapids: Zondervan.

Tanya, V. I. (1996). Spiritualitas, Pluralitas dan Pembangunan di Indonesia. Jakarta: BPK Gunung Mulia

Tischler, L., Biberman, J., \& McKeage, R. (2002). Linking Emotional Intelligence, Spirituality and Workplace Performance. Journal of Managerial Psychology, 17(3), 203-218.

Russell, T. H., Bean, A. C., \& Vaughan, L. B. (Eds). (1938). Webster's TwentiethCentury Dictionary of the English Language. New York: Publishers Guild, Inc.

Wilson, E. (1990). Pola Hidup Kristen: Dosa Seksual dan Pertumbuhan Kristiani. Malang: Gandum Mas. 